\title{
СОЦІАЛЬНЕ ПІДПРИСМНИЦТВО ЯК ІНСТРУМЕНТ СОЦІАЛЬНОЇ ІНКЛЮЗІЇ В УМОВАХ ЕКОНОМІЧНОЇ НЕВИЗНАЧЕНОСТІ
}

\author{
Красота Олена Вадимівна, \\ кандидат економічних наук, доцент, \\ дочент кафедри економічної теорії, макро- і мікроекономіки, \\ Київський національний університет імені Тараса Шевченка, \\ ORCID: http://orcid.org/0000-0001-8840-3119, \\ Андрєєва Віма Анатоліївна, \\ кандидат економічних наук, дочент, \\ доцент кафедри теоретичної та прикладної економіки, \\ ВН3 «Університет економіки та права «КРОК», \\ ORCID: https://orcid.org/0000-0002-6357-3063
}

Анотація. В умовах посилення економічної невизначеності, коли держава демонструє обмежені можливості виконання притаманних ій функцій, виникає необхідність нових підходів до вирішення соціальних проблем. Таким новим підходом може ставати соціальна інклюзія, а одним з ії ефективних інструментів - соціальне підприємництво. Саме цій проблемі - використанню соціального підприємництва в інтересах соціальної інклюзії для обмеження економічної невизначеності присвячено цей розділ.

Ключові слова: соціальна інклюзія/ексклюзія, соціальна політика, соціальне підприємництво, незахищені верстви суспільства.

Українське суспільство продовжує шукати відповіді на виклики, пов'язані 3 негативними наслідками від деіндустріалізації, від недоінвестування, значної імпортозалежності, макрофінансової крихкості, безробіття, низького рівня доходів, значної соціальної нерівності тощо. Ситуація невизначеності ускладнюється війною та інституційною слабкістю держави. Додають гостроти проблемі економічної невизначеності пандемії, екологічні та техногенні катастрофи.

Від економічної невизначеності найбільше потерпають найуразливіші верстви населення - ті, що складають групу соціально ексклюзивних осіб. Водночас, саме 3 ними може бути пов'язане посилення цієї невизначеності. Тому економічна невизначеність та соціальна ексклюзія є взаємно пов'язаними явищами.

Власне термін «соціальна ексклюзія» виник та поширився в середині 1970-х років як реакція на неефективну соціальну політику уряду Франції. Неефективність проявлялася у тому, що окремі групи людей не були охоплені системою соціального захисту, поповнювали ряди люмпенів і не могли брати повноцінну участь у житті громадянського 
суспільства. До таких груп належали люди з обмеженими можливостями, особи пенсійного віку, багатодітні матері, колишні ув'язнені, ВІЛ-позитивні особи тощо. 3 цього часу соціальна ексклюзія розглядається як процес, y результаті якого людина/група людей повністю або частково виключаються з повноцінної участі в житті суспільства. При такому тлумаченні явища ексклюзії акцентується увага на нерівному доступі до економічних ресурсів та на нерівномірному розподілі благ у суспільстві. Визнається, що результатом цієї нерівності стає розшарування суспільства. Відповідно, зростають масштаби економічної невизначеності.

Ми формулюємо припущення, що однією з визначальних умов адекватної реакції на економічну невизначеність може ставати соціальна інклюзія (від англ. inclusion - «залучення», «включення», «охоплення чимось»).

Соціальна інклюзія $є$ відносно новою концепцією з теоретичним інструментарієм, який усе ще перебуває у процесі становлення. Тому термінологічному апарату іноді бракує чіткості та однозначності у тлумаченні змістів.

Упродовж чотирьох десятиліть концепція соціальної інклюзії розвивалася на грунті ідеї гарантування соціальних прав та досягнення вищого рівня добробуту. Наприкінці 1980-х років ця концепція була прийнята Європейським Союзом для формування соціальної політики [1]. У багатьох випадках вона замінила концепцію боротьби з бідністю, яка довгий час перебувала в центрі уваги урядів європейських країн. Розвиток цієї концепції відбувався, головним чином, як реакція на кризу держави загального добробуту в Європі, коли виявилася неспроможність ефективно вирішувати актуальні соціальні проблеми суспільства.

Якщо у розвинених країнах світу соціальна інклюзія вже стала реальною практикою, то в Україні лише відбувається осмислення ідеї та обговорення загальних підходів до ії практичної реалізації.

Ми виходимо з того, що соціальна інклюзія - це не просто протилежність (антипод) соціальної ексклюзії (відторгнення, відчуження), а свідоме формування певного стану суспільства. Ознакою цього стану $\epsilon$ те, що громадяни мають достатні, контрольовані й гарантовані суспільством умови в таких сферах, як:

- споживання благ на основі отримуваних доходів;

- володіння ресурсами та їх використання у процесі продуктивної зайнятості;

- управління через участь в інститутах громадянського суспільства та у прямому народовладді.

Визначальними у реалізації концепції соціальної інклюзії є такі фундаментальні ідеї:

- иінування, визнання і поваги до всіх членів суспільства, попри відмінності в освіті, у віці, в соціальному статусі тощо; 
- причетності та участі в різних сферах життя суспільства, за вільним вибором;

- матеріального добробуту, що передбачає матеріальну та фінансову підтримку вразливих верств;

- дотримання права людини на забезпечення гідного рівня життя.

Соціальна інклюзія є інтегральним явищем суспільного життя. Воно не обмежується лише вирішенням проблем найуразливіших верств суспільства. Виходячи за межі власне соціальної сфери, інклюзія «заходить» своїм змістом в економічну та політичну сфери.

Соціальна інклюзія $\epsilon$ необхідною умовою вирішення низки проблем, що передусім перебувають на межі економічного та соціального. Такою проблемою $\epsilon$, зокрема, працевлаштування вразливих груп населення, які не цікаві для успішного традиційного бізнесу. Адже таке працевлаштування передбачає додаткові витрати для пристосування робочого місця до особливих потреб людей з певними обмеженнями. У цьому та подібному випадках соціальна проблема могла б так $\mathrm{i}$ залишитися без вирішення через економічні обмеження. Тому виникає необхідність у нетрадиційних, більш соціально орієнтованих формах провадження підприємницької діяльності.

Ефективною формою поєднання економічного та соціального й, водночас, інструментом соціальної інклюзії стає особливий вид підприємництва. Його позначають спеціальним терміном - «соціальне підприємництво». Особливою ознакою соціального підприємництва стає інша ієрархія цінностей. Воно спрямоване не стільки на прибутковість бізнесу, скільки на досягнення суспільного добробуту.

Які соціальні проблеми, що стосуються соціальної інклюзії та розвитку соціальної сфери, вирішують соціальні підприємства?

Передусім соціальні підприємства сприяють вирішенню проблеми безробіття. Вони створюються для інтеграції на ринку праці безробітної, малокваліфікованої молоді, людей з інвалідністю тощо. При цьому зайнятість, як інклюзивний процес, не обмежується лише включенням найуразливіших верств населення й лише в ринок праці. Йдеться про створення нових можливостей споживання для осіб, що отримають вищі доходи. Стають доступними нові економічні блага, забезпечуються стандарти гідного життя. Нарешті, відбувається самореалізація у професії.

Зайнятість, завдяки соціальним підприємствам, сприяє інклюзії певних категорій населення у різні сфери суспільного життя. У соціальній сфері зайнятість виконує роль так званого «соціального ліфта». У економічній сфері працююча людина привласнює створений нею, а не перерозподілений державою на ії користь, дохід. У соціокультурній сфері формується потенціал вищого рівня освіти, особа стає частиною трудового колективу, розвиває комунікативні навички, отримує новий соціальний досвід тощо. 
Основні (концептуальні) лінії зв'язку між соціальною інклюзією, соціальним підприємництвом як іï формою, з одного боку, економічною невизначеністю - $з$ іншого, подано на рис. 1.

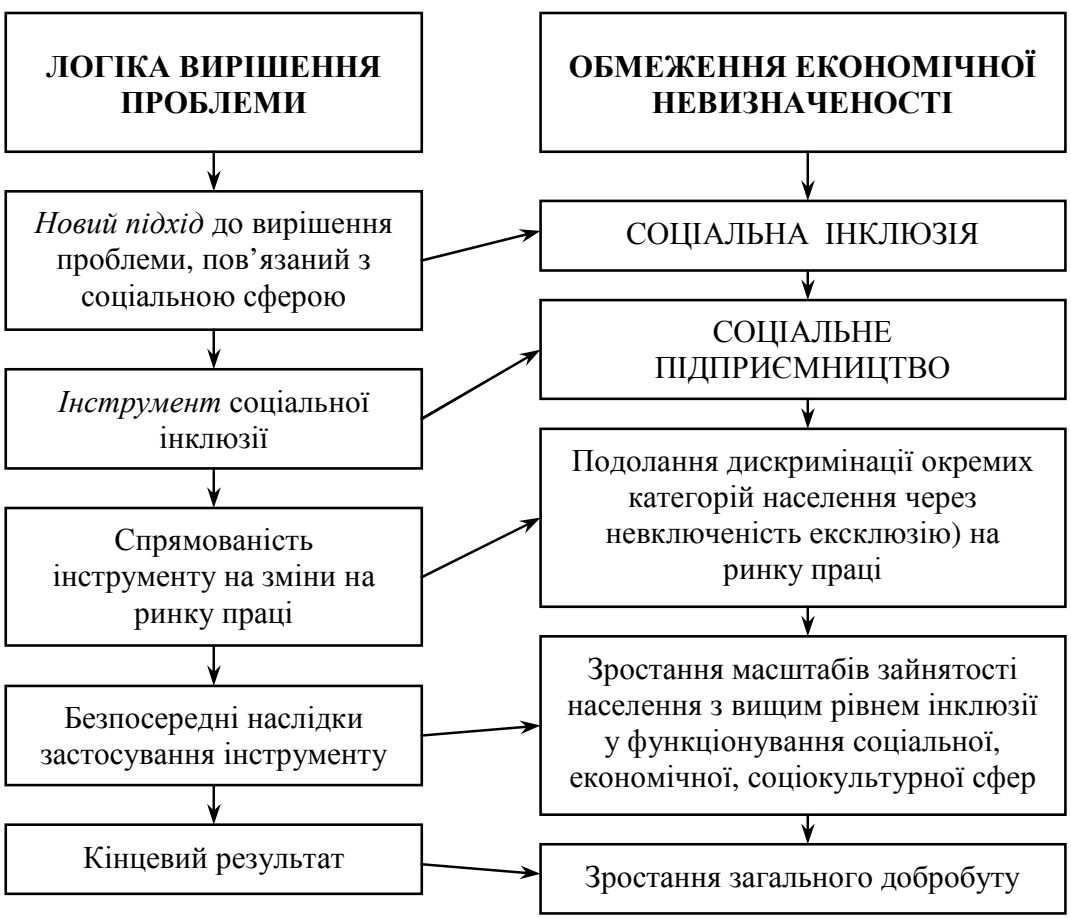

\section{Рис. 1. Взаємозв'язок економічної невизначеності, соціальної інклюзії та соціального підприємництва}

Джерело: складено авторами самостійно.

На рис. 1. ілюстрована ідея, що виключенням певних груп населення 3 трудової діяльності спричиняється вищий рівень невизначеності. Натомість, застосування інструментарію соціальної інклюзії, включно з соціальним підприємництвом, сприяє формуванню більшої економічної визначеності завдяки зайнятості. Остання втілюється у зростанні загального добробуту.

Ми розглядаємо категорію «соціальне підприсмництво» як елемент загальної теорії соціальної інклюзії. Тому уточнення змісту цього явища для нас має принципове значення.

Проблема соціальної інклюзії (ексклюзії) стала предметом наукових досліджень $з$ 1970-х рр. Натомість, соціальне підприємництво активно досліджується з 1990-х рр. 
Теоретичною основою соціального підприємництва вважається концепція так званої «змішаної цінності» Дж. Емерсона. Згідно з цією ідеєю, у будь-якій організації (включно з підприємством) відбувається поєднання економічної та соціальної сфер, які активно формують одна одну [2].

Виокремлюють чотири підходи до визначення природи (основного змісту) соціального підприємництва. Вони подані в аналітичній табл. 1. Таблиия 1

Підходи до визначення змісту соціального підприємництва

\begin{tabular}{|c|c|c|c|}
\hline $\begin{array}{c}\text { Ідентифікація } \\
\text { підходу }\end{array}$ & $\begin{array}{c}\text { Автори } \\
\text { (розробники) }\end{array}$ & $\begin{array}{l}\text { Основні ознаки } \\
\text { соціального } \\
\text { підприсмництва }\end{array}$ & Обмеження підходу \\
\hline $\begin{array}{l}\text { позицій } \\
\text { широкого } \\
\text { тлумачення } \\
\text { змісту }\end{array}$ & \begin{tabular}{|l|} 
Дж. Віравардена, \\
Г. Морт, А. \\
Фоулер, Е. Шоу, \\
пов’язані з \\
діяльністю «Центру \\
з поліпшення \\
соціального \\
підприємництва» \\
\end{tabular} & $\begin{array}{l}\text { Охоплює діяльність широкого } \\
\text { кола організацій, а саме: } \\
\text { - державних соціальних } \\
\text { організацій; } \\
\text { - традиційних бізнес- } \\
\text { організацій, які завжди } \\
\text { мають соціальну складову; } \\
\text { - недержавних неприбуткових } \\
\text { організацій, спрямованих } \\
\text { на досягнення соціальних } \\
\text { цілей }\end{array}$ & $\begin{array}{l}\text { Не акцентуються } \\
\text { особливі ознаки } \\
\text { соціального } \\
\text { підприємництва, } \\
\text { воно ототожнюється } \\
\text { з будь-якою } \\
\text { діяльністю, яка має } \\
\text { соціальний ефект }\end{array}$ \\
\hline $\begin{array}{l}\text { Комбінований } \\
\text { (комерційно- } \\
\text { соціальний) } \\
\text { підхід }\end{array}$ & $\begin{array}{l}\text { А. Макміллан, } \\
\text { Дж. Робінсон, } \\
\text { Я. Рогалін }\end{array}$ & $\begin{array}{l}\text { Охоплює діяльність, яка } \\
\text { орієнтована на досягнення } \\
\text { не лише соціальних, але й } \\
\text { комерційних результатів }\end{array}$ & $\begin{array}{l}\text { Дає відповідь на } \\
\text { питання, у якому } \\
\text { поєднанні } \\
\text { відбувається } \\
\text { соціальна діяльність, } \\
\text { але не розкриває } \\
\text { власне зміст } \\
\text { соціального } \\
\text { підприємництва } \\
\end{array}$ \\
\hline $\begin{array}{l}\text { Інноваційний } \\
\text { підхід }\end{array}$ & \begin{tabular}{|l|} 
Дж.Вей-Скіллерн, \\
С. Вурро, Дж. Мейр, \\
Е. Нобоа, Е. Остін, \\
Ф. Перріні, \\
Х. Стівенсон
\end{tabular} & $\begin{array}{l}\text { Є частиною діяльності } \\
\text { інноваційних підприємств, } \\
\text { які зазвичай спрямовуються } \\
\text { на вирішення соціальних } \\
\text { проблем }\end{array}$ & \begin{tabular}{|l|} 
Не акцентується \\
можливість \\
досягнення \\
соціальних цілей \\
неінноваційними \\
підприємствами \\
\end{tabular} \\
\hline $\begin{array}{l}\text { Проблемно- } \\
\text { орієнтований } \\
\text { підхід }\end{array}$ & \begin{tabular}{|l|} 
К. Лідбітер, \\
аналітики «Фонду \\
Шваба»
\end{tabular} & $\begin{array}{l}\text { Є діяльністю, соціальні } \\
\text { результати якої спрямовані } \\
\text { на певну соціальну групу - } \\
\text { людей з інвалідністю, } \\
\text { безхатченків тощо - або на } \\
\text { вирішення загальних } \\
\text { соціальних проблем, } \\
\text { пов'язаних з екологією, } \\
\text { енергетикою тощо }\end{array}$ & $\begin{array}{l}\text { Як різновид } \\
\text { широкого підходу, } \\
\text { не акцентує на } \\
\text { особливостях } \\
\text { соціального } \\
\text { підприємництва, } \\
\text { лише виокремлюючи } \\
\text { результат його } \\
\text { діяльності та } \\
\text { споживачів цих } \\
\text { результатів }\end{array}$ \\
\hline
\end{tabular}

Джерело: складено на основі джерела [3]. 
3 аналізу інформації, поданої в аналітичній табл. 1, випливає, що в науковому обігу використовуються переважно «широкі» тлумачення соціального підприємництва. Це - його тлумачення як діяльності без акцентування на особливостях та відмінностях такого підприємництва. Спільною рисою чотирьох розглянутих підходів $\epsilon$ визнання соціальної мети, яка, однак, тлумачиться по-різному.

На наш погляд, при визначенні соціального підприємництва, крім соціально визнаних результатів його діяльності, має відзначатися й інше. Йдеться про факт пріоритетності соціальних цілей над економічною метою максимізації прибутку та про спрямування прибутку на вирішення соціально важливих завдань громад чи суспільства. Отримання прибутку залишається метою соціального підприємництва саме як підприємництва. Але вона може мати для нього нижчі позиції в рейтингу цінностей, ніж соціальні цілі, включно з ціллю інклюзії. До того ж ознакою соціального підприємництва має бути переважання в управлінні демократичних засад над авторитарними. В іншому випадку, соціальні цілі можуть «відсуватися на вторинні позиції» через авторитарні методи управління.

Показово те, що фіксація того, що соціальне підприємство, як економічний суб'єкт, має орієнтуватися на отримання прибутку, відповідає документам офіційних органів ЄС. За цими документами [4; 5], соціальне підприємництво має відповідати таким критеріям:

- здійснювати реальну економічну діяльність;

- мати чітку соціальну мету, яка $є$ корисною для суспільства;

- отримувати прибуток, але мати обмеження на його розподіл та розподіл активів з метою забезпечення пріоритетності соціальної мети діяльності;

- бути незалежним від держави чи інших некомерційних організацій у проєктуванні своєї діяльності;

- забезпечувати інклюзивне (внутрішнє) управління та демократичні процедури прийняття рішень.

Важливо те, що згадані критерії сформульовані, усвідомлені та ними фактично почали керуватися творці українського соціального підприємництва [6].

У діяльності соціального підприємства виникає та постійно виявляється суперечність двох сторін діяльності - соціальної та економічної. 3 метою спрощення, ми використовуватимемо поняття економічна, підприємницька, комерційна сторона діяльності соціального підприємства як синоніми. Між соціальним та економічним у діяльності соціальних підприємств існує складна система взаємодії. Саме вона має ставати об'єктом дослідження при уточненні змісту поняття «соціальне підприємництво». Наші уявлення про особливості взаємодії двох сторін соціального підприємництва, які сформовані на основі вивчення досвіду 
соціального підприємництва інших країн та досвіду українських соціальних підприємств, подано на рис. 2.

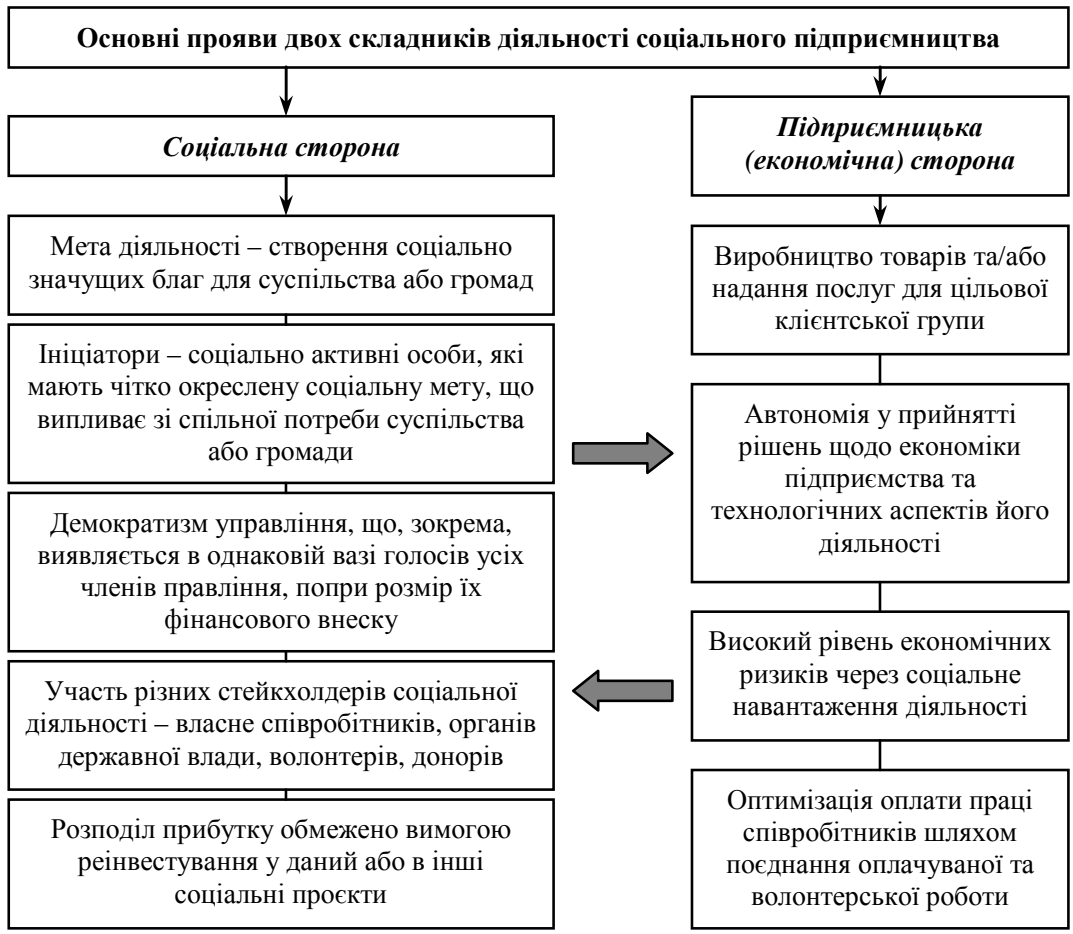

Рис. 2. Складники соціального підприємництва

Джерело: складено авторами самостійно.

На рис. 2 подано ті елементи соціального та економічного складників діяльності соціальних підприємств, зв'язок між якими пояснює об'єктивну суперечність соціального підприємництва. Вона (суперечність) виявляється у тому, що соціальна спрямованість, прагнення мінімізувати витрати 3 оплати праці заради збільшення реінвестованого прибутку тощо можуть спричиняти зменшення економічної ефективності. Це створює додаткові економічні ризики для підприємства саме як соціального. Певні ризики неефективної діяльності може породжувати й надмірна демократизація управлінського процесу.

Якщо соціальне підприємництво сприяє соціальній інклюзії, то принципово важливим для пояснення цього сприяння стає дослідження власне каналів впливу. На наш погляд, соціальне підприємництво визначає соціальну інклюзію через такі канали: 
- включення громадян у спільну діяльність, пов'язану з реалізацію соціальних проєктів;

спільну справу;

- формування персональної та групової відповідальності за

- розширення можливостей створення додаткових робочих місць та додаткової зайнятості;

- подолання соціальної ізольованості осіб 3 обмеженими можливостями;

- зміцнення громад шляхом активізації громадської діяльності членів цих громад;

- руйнування бар'єрів в уявленні громадян щодо престижної та непрестижної діяльності, відповідно, бар'єрів у взаєминах між громадянами;

- збільшення потенціалу вирішення соціальних проблем на рівні місцевих громад при зменшенні навантаження на місцеві бюджети;

- формування нових зразків та способів надання соціальних послуг у партнерських взаєминах бізнесу, місцевих громад та органів центральної державної влади.

Оскільки Україна не є лідером у соціальному підприємництві, то для української економіки та суспільства принципово важливим стає усвідомлення досвіду соціального підприємництва інших країн. Попри існування особливостей у кожній національній моделі соціального підприємництва, є підстави для виокремлення двох базових моделей. Щодо них можуть застосовуватися терміни «американська модель» та «європейська модель». Попри широке застосування цих термінів, показовим є те, що у багатьох країнах немає законодавчо закріпленого поняття «соціальне підприємництво». А уніфіковані підходи до ідентифікації соціальних підприємств у ЄС відсутні [7].

Інформація про особливості (відмінності) так званих американської та європейської моделей соціального підприємництва подана на рис. 3.

На рис. 3 подано ідею про те, що основна відмінність двох моделей соціального підприємництва пов'язана з акцентом на певному боці їх діяльності. В американській моделі більше акцентовано економічний (підприємницький, комерційний) бік діяльності. Натомість, у європейській моделі робиться більший акцент на соціальній спрямованості діяльності. Ці акценти віддзеркалені й у різному ставленні до оптимізації прибутку: значення прибутку в американській моделі соціального підприємництва $є$ більшим. Натомість, європейська модель є більш «патерналістською»: роль держави у ній помітніша. Американська модель соціального підприємництва сформувалася як реакція на згортання фінансування неприбуткових організацій у соціальній сфері. Більш ліберальний характер американської моделі виявляється, врешті-решт, у меншому рівні інклюзії. Натомість, європейська модель дає можливість забезпечувати вищий рівень соціальної інклюзії. 


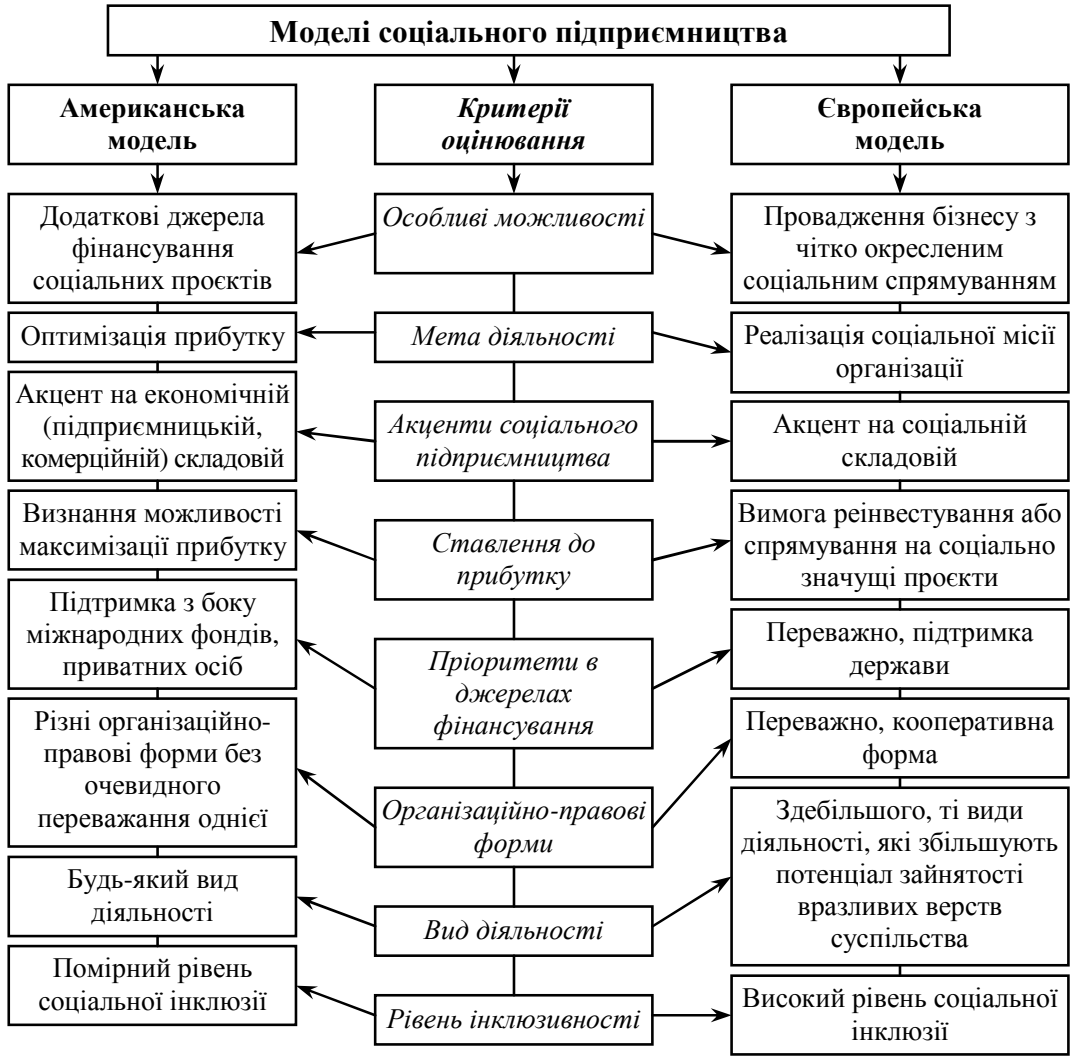

\section{Рис. 3. Ознаки двох базових моделей соціального підприємництва} Джерело: складено авьлоами на основі [8].

Є підстави для припущення, що власне назві «соціальне підприємництво» більше відповідають підприємства, організовані за логікою європейської моделі. Європейська модель соціального підприємництва - це «бізнес із соціальною місією» та 3 чітко акцентованим та підтримуваним соціальним ефектом діяльності. Досягнення цього ефекту стимулюється державою через законодавство, пільги та дотації.

Американській моделі могла би пасувати, до прикладу, назва «підприємництво, імплементоване в соціальну систему». В ній ідеться про різні способи сприяння підприємствам, що виконують соціальні функції. Це - фінансова, дослідницька, освітня підтримка міжнародних і приватних організацій, державні й федеральні програми реабілітації та працевлаштування осіб з особливими потребами, врахування факту задоволення цих потреб при наданні переваг та пільг підприємцям. 
На тлі двох базових моделей соціального підприємництва доцільно досліджувати та акцентувати особливості соціального підприємництва в окремих країнах. Це допомагатиме у відборі тих форм та інструментів впливу, які можуть сприяти формуванню української моделі соціального підприємництва. Спробуємо виокремити ті національні особливості, що виявляються в організаційних формах соціального підприємництва [9-11].

Типовою формою організації соціального підприємництва у більшості країн Європи є кооперативи. У Франції вони, до прикладу, називаються «кооперативами спільного інтересу», в Італії - «соціальними кооперативами». В Іспанії, Португалії, Франції, Греції, Хорватії соціальне підприємство може існувати виключно у формі соціальних кооперативів.

Соціальними підприємництвом у США вважається діяльність неприбуткових недержавних організацій, дохід яких використовується на статутні цілі організації, найчастіше, на вирішення соціальних проблем певних цільових груп громадян. У США достатньо, щоб товар або послуга сприяли вирішенню певної соціальної проблеми. I тоді підприємство, яке виробляє такий товар або надає таку послугу, вже може називатися соціальним.

У Великій Британії впроваджено спеціальний різновид соціального підприємництва - компанії, що працюють в інтересах громад. У країні діє понад 13 тисяч таких компаній. Велика Британія вважається європейським лідером. У країні діє близько 70 тис. соціальних підприємств, що забезпечують роботою майже мільйон британців. Їхній сумарний внесок в економіку становить понад 24 млрд фунтів стерлінгів. За підсумками 2017 р., 68\% соціальних підприємств підтримували людей 3 уразливих груп, 44\% - працевлаштовували таких людей, $28 \%$ - працювали в найбільш депресивних районах країни, формуючи економіку цих регіонів.

У Бельгії, Данії, Фінляндії, Люксембургу, Словенії статус соціального підприємства можуть отримати не лише кооперативи чи приватні компанії, а й громадські, волонтерські, благодійні організації та фонди.

У Латвії діє закон, за яким соціальні підприємства можуть існувати тільки у формі товариства 3 обмеженою відповідальністю (ТОВ). Їх соціальний статус має щороку підтверджувати відповідне міністерство. Держава звільняє соціальні підприємства від сплати податку на прибуток.

В Австрії, Бельгії, Іспанії, Італії, Нідерландах, Словенії, Фінляндії, Швеції поширена така форма соціальних підприємств, як «підприємства трудової інтеграції» (Work Integration Social Enterprise). Їх мета - це надання допомоги у працевлаштуванні та професійній підготовці незахищеним верствам громадян. 
Соціальне підприємництво не може існувати без державної підтримки. Для європейських країн - це не лише підтримка національних урядів, а й керівних органів СС. Ще у 2011 р. Європейська комісія схвалила довгострокову програму розвитку соціального підприємництва «ніціатива соціального підприємництва» (Social Entrepreneurship Initiative) [12]. Мета програми - стимулювати країни європейського регіону на розвиток сектору соціального підприємництва. Програма має три основні фокуси: популяризація діяльності соціальних підприємств, дружнє до соціальних підприємців законодавче середовище, створення умов для простішого отримання фінансування.

Європейська комісія виокремлює такі основні сфери соціального підприємництва:

- надання індивідуальних соціальних послуг у сфері охорони здоров'я, соціального захисту, освіти;

- догляд за дітьми, особами похилого віку, допомога малозабезпеченим;

- працевлаштування осіб, які опинилися у складних життєвих обставинах, та безробітних;

- місцевий розвиток депресивних/уразливих регіонів;

- переробка сміття, захист навколишнього середовища, спорт, мистецтво, культура, наука, дослідження та інновації, захист прав споживачів.

Перелік сфер соціального підприємництва у документах керівних органів ЄС важливий, окрім іншого, ще й тому, що віддзеркалює європейське тлумачення поняття «соціальне». Як свідчить перелік, цим поняттям охоплюються не лише явища, пов'язані з нерівністю людей у суспільстві. «Соціальне» тлумачиться також у зв'язку з процесами, які формують загальний рівень добробуту в країні. Це - не лише доходи й зайнятість, а й стан довкілля, культури, освіти, здоров'я громадян.

Реакція на створені умови та стимули для соціального підприємництва може аналізуватися за даними про кількість соціальних підприємств у окремих європейських країнах. Ця інформація подана на рис. 4.

Інформація з рис. 4 свідчить про різний потенціал соціального підприємництва у різних країнах. Це $є$ цілком природним, з огляду на відмінності у кількості та структурі населення країни, у рівні економічного розвитку. Однак, статистика соціальних підприємств засвідчує достатньо контроверсійний факт суттєвих (у рази) відмінностей між країнами 3 приблизно однаковим економічним потенціалом. Ідеться, зокрема, про трьох європейських лідерів - Францію, Німеччину та Велику Британію. Кількість підприємств у Німеччині у 2,7 рази є більшою, ніж у Франції, а у Великій Британії - у 1,7 разів більшою, ніж у Німеччини. Цей феномен потребує дослідження з метою з'ясування, що спричиняє відмінності: законодавство, державна підтримка чи особливості статистики соціальних підприємств. 


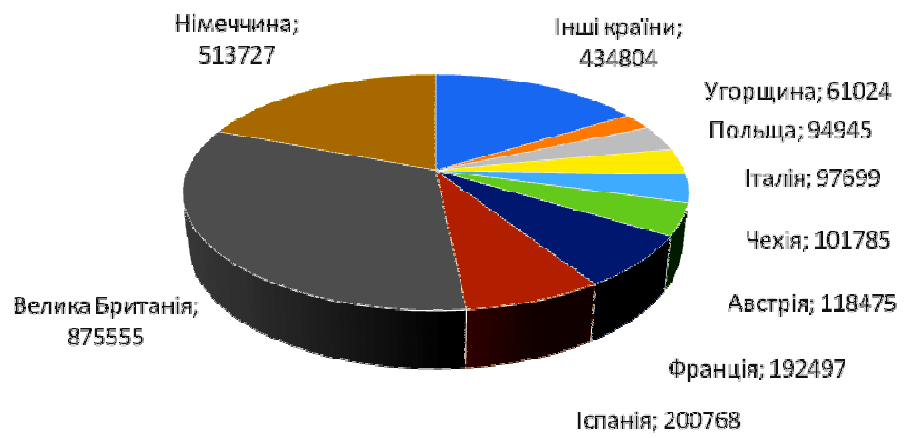

\section{Рис. 4. Кількість соціальних підприємств у країнах ЄС та Великій Британії, 2017 р.}

Джерело: складено на основі [13].

Українське соціальне підприємництво перебуває у зародковому стані, з огляду на зафіксовану кількість - 150 соціальних підприємств. У еволюції українського соціального підприємництва виокремлюють три етапи.

Периий етап (1991 - 2010 рр.) відзначився ініціативами міжнародних донорів, передусім USAID, які спонукали уряд та суспільство до розбудови системи соціального захисту. Насамперед ішлося про захист людей з певними обмеженнями та особливими потребами. Першим законодавчим актом, в якому присутня ідея інклюзії (хоча відсутній власне термін), став спеціальний Закон України №875-12 [14], прийнятий ще у 1991 році. Цей Закон є досі чинним та передбачає додаткові преференції для підприємницької діяльності з залученням людей 3 інвалідністю. Ним також передбачається діяльність спеціального фонду фінансування бізнес-ініціатив громадян України, що мають певні обмеження. У такий спосіб, завдяки Закону, створено певні умови для соціального підприємництва. Однак, підприємницька діяльність людей $з$ обмеженими можливостями не отримала назву «соціальне підприємництво».

Уперше термін «соціальне підприємництво» почав використовуватися в Україні лише в 2000-х рр. та дістав поширення завдяки «Мережі громадської дії в Україні» (UCAN). Мережа підтримувала діяльність 28-х українських соціальних підприємств, що існували в той час.

Другий етап (2010 - 2015 рр.) пов'язаний зі зростанням кількості досліджень про соціальне підприємництво, з розвитком відповідних програм та організаційних структур підтримки. Одним 3 перших, відзначених українською науковою спільнотою, стало дослідження українського автора К. Смаглій, яке побачило світ у 2014 р. [15]. У 2010 р. створено Консорціум «Сприяння розвитку соціального підприємництва в 
Україні». До нього увійшло 5 міжнародних організацій, що визначили за мету фінансову, освітню, консультативну допомогу соціальним підприємствам, які тільки-но розпочинали діяльність. Позитивним результатом діяльності Консорціуму стало те, що у декількох великих містах України соціальні підприємства почали активно діяти. А відповідальність за їх підтримку здебільшого почали брати на себе місцеві громади та місцевий бізнес.

На цьому етапі були створені такі організаційні форми підтримки українського соціального підприємництва, як Всеукраїнський ресурсний центр розвитку соціального підприємництва «Соціальні ініціативи», портал socialbusiness.in.ua з першим реєстром соціальних підприємств, програма соціального інвестування для соціальних підприємств 3 відносно невисокими процентами за кредит.

Tpemiŭ eman (початок 2016 р. й дотепер) характеризується зростанням кількості соціальних підприємств, розширенням кола суб'єктів, які підтримують соціальне підприємництво. Зокрема, на цьому етапі активно долучилися український малий та середній бізнес, українські університети. Значну роль продовжують відігравати міжнародні організації. На цьому етапі відбулися зміни акцентів у діяльності соціальних підприємств. Сучасне українське соціальне підприємництво та волонтерський рух долають наслідки російсько-української війни на Сході України. Предметом уваги стають біженці, діти прифронтових територій, воїни, які потребують реабілітації після поранень, родини загиблих тощо.

Саме на третьому етапі в українських університетах почали викладатися навчальні курси з соціального підприємництва. Відповідно, почали готуватися професіонали з необхідними компетентностями.

3 огляду на значну фінансову та консультативну підтримку соціального підприємництва 3 країн $Є С$, можна було б сподіватися тиражування в Україні європейської моделі. За критерієм пріоритетності соціального над економічним, європейська модель в Україні, дійсно, частково реалізується. Але українській національній моделі бракує другої частини європейської моделі, а саме: послідовної економічної державної підтримки. У цій другій частині українська модель соціального підприємництва більше нагадує американську 3 iї ініціативними приватними фондами та громадянами.

Виглядає так, що відбувається створення української національної моделі соціального підприємництва з особливими ознаками. В їі межах соціальні підприємці вимушено перебирають на себе ті соціальні функції, які не виконує держава, хоча мала би виконувати за законодавством. Причинами невиконання державою належних їй соціальних функцій в українській дійсності стають: слабкість інститутів державної влади, брак політичної волі, сформована олігархічна модель економіки 3 несоціальними цінностями тощо. 


\section{Висновки:}

За результатами аналізу зв'язку між соціальною інклюзією та соціальним підприємництвом, 3 одного боку, та економічною невизначеністю - з іншого, можемо зробити такі узагальнення.

Соціальне підприємництво як форма соціальної інклюзії, незаперечно, розширює масштаби економічної визначеності. Адже через соціальні підприємства досягається більше охоплення громадян трудовою діяльністю, отримання ними зароблених (факторних), а не перерозподілених доходів, забезпечується розвиток професійних та комунікативних навичок, активізується участь в управлінні та в інститутах влади.

Одночасно, соціальне підприємництво має певний потенціал розширення економічної невизначеності. Він пов'язаний з суперечністю між соціальним та економічним боком діяльності, яка [суперечність] виявляється у тому, що прерогатива соціального може породжувати втрату економічної ефективності.

Суперечність між соціальним та економічним у діяльності соціальних підприємств вирішується в межах конкретної національної моделі соціального підприємництва. Ця модель означає існування особливих вимог держави до організаційних форм соціального підприємництва, а також особливих інструментів державної підтримки та форм взаємодії з інститутами громадянського суспільства, 3 міжнародними організаціями, з місцевими громадами та несоціальним бізнесом.

Імовірно, що в Україні формується змішана модель соціального підприємництва, яка вимушено поєднує певні ознаки так званих європейської та американської моделей. Ця змішаність значною мірою визначається лакунами (провалами) діяльності сучасної української держави у виконанні соціальних функцій, відповідно, в забезпеченні соціальних гарантій та стандартів.

\section{Jimepamypa:}

1. Monitoring social inclusion in Europe edited by Anthony B. Atkinson, Anne-Catherine Guio and Eric Marlier. 2017. URL : https://scholar.google.com.ua/citations?user=QgmO3FAAAAAJ\&hl=uk\&oi=sra.

2. Emerson J. The blended value map: Tracking the Intersects and Opportunities of Economic, Social and Environmental Value Creation. 2003. URL : https://community-wealth.org/content/blended-value-maptracking-intersects-and-opportunities-economic-social-and-environmental.

3. Соціальне підприємництво: від ідеї до суспільних змін : посібник / А. Свинчук, А. Корнецький, М. Гончарова, В. Назарук, Н. Гусак, А. Туманова. Київ : ТОВ «ПІДПРИЄМСТВО «ВІ ЕН ЕЙ», 2017. 188 с. 
4. Social Enterprise in Europe Developing Legal Systems which Support Social Enterprise Growth. URL : http://www.bwbllp.com/knowledge/ 2015/10/21/ocial-enterprise-in-europe-developing-legal-systems-which-supportsocial-enterprise-growth/.

5. Defourny J., Nyssens M. Social Enterprise in Europe: Recent Trends and Developments. 2008. URL : http://www.emes.net/site/wp-content/ uploads/WP_08_01_SE_WEB.pdf.

6. Зелена книга соціального підприємництва в Україні, Український форум благодійників, Інститут інклюзивного розвитку. Київ, 2019.

7. European Commission A map of social enterprises and their ecosystems in Europe. Synthesis Report. 2014. URL : https://www.age-platform. eu/publications/map-social-enterprises-and-their-eco-systems-europe.

8. Школяр М. В. Соціальне підприємництво як інструмент вирішення соціальних проблем. Науковий вісник НЛТУ Украӥни. Серія економічна. 2017. Вип. 27. №2. С. 85-89.

9. Duniam M., Eversole R. Social Enterprises and Local Government: A Scoping Study. Australian Centre of Excellence for Local Government. 2013. $23 \mathrm{p}$.

10. The European Social Enterprise Law Association. URL : http://www.socialenterprisebsr.net/2015/12/the-european-social-enterpriselaw-association/.

11. Social enterprise: market trends. 2017. URL : https://www.gov.uk/ government/publications/social-enterprise-market-trends-2017. The European Social Enterprise Law Association. URL : http://www.socialenterprisebsr. net/2015/12/the-european-social-enterprise-law-association/.

12. Social Entrepreneurship Initiative. URL : http://ec.europa.eu/ growth/sectors/social-economy/enterprises/index_en.htm.

13. Social enterprise: market trends 2017. URL : https://www.gov. uk/government/publications/social-enterprise-market-trends-2017.

14. Про основи соціальної захищеності осіб з інвалідністю в Україні : Закон України №876-12 від 21.03.1991 p. URL : https://zakon. rada.gov.ua/laws/show/875-12\#Text.

15. Смаглій К. Зміни творить кожен із нас: соціальне підприємництво та стратегічна філантропія. Київ : Видавничий дім «Києво-Могилянська академія», 2014. 